\title{
Kelas Menengah Muslim Baru dan Kontestasi Wacana Pluralisme di Media Sosial \\ Oleh:
}

\section{Subkhi Ridho ${ }^{1}$}

\begin{abstract}
Abstraksi
Artikel ini mengelaborasi narasi tentang tumbuhnya kelas menengah Muslim baru pada masa Reformasi dan sikap mereka terhadap wacana pluralisme di media sosial. Kemunculan kelas menengah Muslim baru merupakan dampak dari stabilnya pertumbuhan ekonomi di Indonesia sejak 2001-2010 dalam bidang fesyen, kosmetik, perbankan, biro travel, budaya populer, wisata religi. Pada saat bersamaan muncul pemahaman akan adanya program liberalisasi pemikiran Islam di Indonesia khusunya pasca peristiwa 9/11 di Amerika Serikat. Program tersebut dijalankan dalam bentuk pewacanaan mengenai pluralisme agama, sekulerisme, kesetaraan gender. Dalam konteks ini, media sosial menjadi sarana persebaran gagasan oleh kelas menengah Muslim tentang bahaya sekulerisme, pluralisme, dan liberalisme (ideologi Barat). Di sisi lain mereka juga melakukan komodifikasi Islam dengan memperdagangkan fesyen, makanan, penerbitan dengan dalih untuk menyelamatkan generasi Muslim dari pengaruh ideologi Barat itu.
\end{abstract}

Kata kunci: kelas menengah Muslim, wacana pluralisme, media sosial.

\begin{abstract}
This article elaborates on the narrative of a growing new Muslim middle class in the Reform era and their attitudes towards the discourse of pluralism in the new media such as social media. The emergence of the new Muslim middle class was a result of a stable economic growth in Indonesia since 2001-2010 who occupy the areas of fashion, cosmetics, banking, travel agencies, popular culture, and religious tourism. At the same time, an understanding of a liberal Islamic thought is developed through a particular program in Indonesia as a response to the post 9/11 in the United States. The program is administered through a discourse on religious pluralism, secularism, and gender equality (Western ideologies). In this context, social media serves as a means of disseminating ideas about the dangers of secularism, pluralism and liberalism brought by the Muslim middle class. On the other hand, they also commodify Islam by trading fashion, food, and publishing under the pretext of saving Muslims from the influence of the Western ideologies.
\end{abstract}

Keywords: Muslim middle class, discourse on pluralism, social media

\section{A. Pendahuluan}

Tumbuhnya kelas menengah baru di Indonesia sejak satu dekade terakhir semakin menunjukkan pentingnya peran mereka ke publik. Diskursus dalam kelas sosial nyaris selalu memosisikan kelas menengah sebagai aktor perubahan yang sesungguhnya. Hal tersebut didukung oleh kekuatan modal yang mereka miliki. Meminjam istilah Bourdie (1994), kelas menengah itu memiliki kapital atau modal sekurang-kurangnya empat yakni: kapital ekonomi, budaya, sosial, dan simbolik. Dalam bahasa Kharas (2010), kelas menengah memiliki gagasan-gagasan baru, akumulasi modal fisik dan modal sumber daya manusianya itu sendiri.

\footnotetext{
${ }^{1}$ Subkhi Ridho adalah aktivis pluralisme dan demokrasi. Saat ini menjadi staf pengajar di Jurusan Ilmu Komunikasi Universitas Muhammadiyah Yogyakarta dan IAIN Surakarta.
} 
Jurnal Pemikiran Sosiologi Volume 4 No. 2, 2017

Kelas Menengah Muslim Baru dan Kontestasi Wacana Pluralisme di Media Sosial

Subkhi Ridho

Kekuatan kapital (modal) yang demikian itu digunakan oleh kelas menengah sebagai sarana untuk melakukan akselerasi perubahan sosial, politik, dan ekonomi masyarakat.

Berdasarkan data World Bank pada 2011 disebutkan bahwa jumlah kelas menengah di Indonesia mencapai 134 juta jiwa, yang di dalamnya termasuk kelas menengah Muslim baru yang tumbuh pasca reformasi 1998. Jumlah tersebut mengalami peningkatan terus hingga hari ini, apalagi pertumbuhan ekonomi Indonesia berjalan secara stabil. Saat ini kelas menengah Muslim baru lebih mudah mengekspresikan identitas keislamannya dibanding pada zaman Orde Baru, yang merepresi praktik-praktik penggunaan identitas Islam di ruang publik, ${ }^{2}$ meskipun menjelang turun sikap rezim melunak. ${ }^{3}$ Praktik bisnis dan barang-barang yang berlandaskan pada syariah digemari dan diburu oleh mereka. Dengan mudahnya kita menjumpai gerai-gerai busana Muslim, bank syariah, sekolah-sekolah beridentitas Islam yang berbiaya tinggi, tayangan sinetron "Islami", salon, pegadaian, hingga hotel yang berlabel syariah (Fealy and White, 2008). ${ }^{4}$ Hal ini ini dikarenakan agama, sebagaimana Geertz (1992) katakan, telah membentuk suatu struktur psikologis dalam benak manusia yang membentuk pandangan

\footnotetext{
2 Penggunaan jilbab oleh para siswi di sekolah-sekolah menengah umum pada tahun 1982 dilarang oleh Surat Keputusan Departemen Pendidikan dan Kebudayaan dengan surat bernomor No.052/C/Kep/D/1982, peraturan ini mendorong aksi demonstrasi di beberapa kota besar; Jakarta, Bandung, Bogor, dan Yogyakarta. Sejak 1970-1990 umat Islam Indonesia betul-betul mengalami marjinalisasi yang begitu rupa; baik melalui politik resmi, melalui rekayasa politik, dan melalui politik keamanan. Baca Kuntowijoyo, Muslim Tanpa Masjid (Bandung: Mizan, 2001), hlm. 309-310.

3 Orde Baru mengakomodasi permasalahan penggunaan jilbab di sekolah umum, dengan mengeluarkan peraturan
}

hidupnya, yang menjadi sarana individu atau kelompok individu yang mengarahkan tingkah laku. Muncul pertanyaan, apakah perilaku kelas menengah Muslim baru dalam berbisnis yang menggunakan label syar'i apakah sungguh-sungguh menjadikan nilai-nilai Islam sebagai dasar inspirasi bagi suatu kerangka nasional dalam masyarakat demokratis dan menampakkan kontribusinya bagi kemajuan bangsa Indonesia di masa mendatang atau justru sekadar menjadikan Islam sebagai komodifikasi agama yang seakan-akan tidak terhindarkan?

Kehadiran media baru, khususnya media sosial seperti Facebook, Twitter, Pinterest, Path, Line, Instagram, Bigo live, WhatsApp, Telegram, dll., turut pula meneguhkan identitas kelas menengah Muslim baru. Beragam komunikasi dan informasi dapat disebarluaskan secara cepat dalam hitungan detik, mengalahkan media konvensional cetak dan elektronik seperti koran, majalah, buletin, tabloid, televisi, radio secara perlahan mengalami penurunan pengguna. Di dalam media sosial pula kelas menengah Muslim baru ini saling berinteraksi satu sama lain dengan melakukan pertukaran informasi mengenai apapun; doktrin-doktrin Islam, kondisi ekonomi, tips berbisnis, saran maupun kritik terhadap kinerja pemerintah, peristiwa-peristiwa

baru melalui Dirjen Dikdasmen dengan surat bernomor Nomor 100/C/Kep/D/1991 yang berisi tentang kebolehan para siswi Muslimah menggunakan jilbab di sekolah menengah umum. Penghapusan SDSB, SKB Mendagri dan Menag mengenai pengumpulan zakat, pendirian Bank Muamalat se-Indonesia, penayangan bahasa Arab di TVRI, Festival istiqlal adalah beberapa bentuk akomodasi Orde Baru terhadap umat Islam.

${ }^{4}$ Ulasan mengenai ekspresi kaum Muslim di Indonesia yang begitu dekat praktik komodifikasi Islam melalui aktifitas perekonomian baca Greg Fealy dan Sally White, Expressing Islam: Religious Life and Politics in Indonesia (Singapore: ISEAS, 2008). 
Jurnal Pemikiran Sosiologi Volume 4 No. 2, 2017

Kelas Menengah Muslim Baru dan Kontestasi Wacana Pluralisme di Media Sosial

Subkhi Ridho

yang terjadi di negara-negara Islam di belahan dunia lain seperti di Mesir, Palestina, Suriah, dll., termasuk di dalamnya informasi hoax yang seringkali minus verifikasi namun langsung disebarluaskan.

Kehadiran media sosial satu sisi mempermudah komunikasi dan pertukaran informasi antar individu, termasuk dimanfaatkan oleh kelas menengah Muslim baru secara masif di berbagai bidang; ekonomi, politik, budaya, dll. Sistem demokrasi yang diadopsi oleh Indonesia pasca reformasi 1998, memberikan ruang yang begitu besar akan tumbuhnya politik identitas yang berkembang saat ini. Termasuk politik identitas yang dimanfaatkan oleh tumbuhnya kelas menengah Muslim baru di Indonesia tak lepas karena dukungan media sosial yang memberikan banyak pilihan. Indonesia dibangun $\mathrm{di}$ atas keberagaman agama, etnis, ras, gender, golongan yang tersebar dari ujung barat yaitu Sabang di Aceh hingga ujung timur yakni Merauke di Papua. Pertanyaannya kemudian adalah, apa dan bagaimana peran kelas menengah Muslim baru dalam mengelola keberagaman bangsa Indonesia melalui media sosial? Jika ada, kira-kira dalam bentuk apa, dan jika belum terlihat, mengapa bisa terjadi? Lalu bagaimana cara mengatasinya? Artikel ini akan menguraikannya lebih jauh kaitannya keberadaan kelas menengah Muslim baru dengan kontestasi wacana pluralisme yang ada di media sosial.

\section{B. Metode Analisis Wacana dan Pembahasan Kelas Menengah Muslim Baru di Indonesia}

Analisis wacana merupakan metode yang digunakan di dalam pembahasan di dalam artikel ini. Analisis wacana merujuk pada bagaimana suatu pewacanaan disusun dan merangkai suatu argumentasi. Dalam konteks ini, wacana yang dirujuk adalah wacana mengenai pluralisme dan bagaimana kelas menengah Muslim di Indonesia meresponnya melalui media sosial, serta bagaimana pluralisme itu sendiri diwacanakan melalui tafsir Islam. Kemunculan kelas menengah Muslim baru ini tak luput dari rilis World Bank pada 2011 mengenai siapa yang disebut kelas menengah dalam masyarakat Indonesia. World Bank menegaskan bahwa yang disebut sebagai kelas menengah adalah mereka yang pengeluarannya 2-20 USD per hari. Sementara itu mereka yang pengeluarannya di bawah 2 USD per hari dikategorikan sebagai miskin, adapun yang pengeluarannya di atas 20 USD per hari masuk kategori kelas atas. World Bank menyebutkan bahwa pada tahun 2012 tidak kurang dari 56,5 persen penduduk Indonesia merupakan kelas menengah. Senada dengan World Bank, pada tahun 2010 ADB menyebutkan bahwa kelas menengah yaitu mereka yang pengeluaran perkapita sebesar 2-20 USD perhari. Indikator kelas menengah di Asia, termasuk di Indonesia, banyak yang mengacu pada definisi yang dibuat oleh ADB. Secara lebih detail, ADB membagi pengeluaran perkapita tersebut dibagi lagi menjadi tiga kelompok yaitu masyarakat kelas menengah bawah (lower middle class) dengan pengeluaran perkapita sebesar 2-4 USD perhari; kelas menengah tengah (middle-middle class) sebesar 4-10 USD perhari; dan kelas menengah atas (upper-middle class) 10- 
Jurnal Pemikiran Sosiologi Volume 4 No. 2, 2017

Kelas Menengah Muslim Baru dan Kontestasi Wacana Pluralisme di Media Sosial

Subkhi Ridho

20 USD perhari sesuai dengan keseimbangan kemampuan berbelanja (purchasing power parity/PPP tahun 2005). Maka pengeluaran 2-20 USD perhari maka didapatkan jumlah kelas menengah Indonesia sebanyak 134 juta (2010) atau sekitar 56\% dari seluruh penduduk, sebuah angka yang tidak kecil.

Sementara itu survei harian Kompas menyebut jumlah kelas menengah 50,3 persen dari total jumlah penduduk. Lebih lanjut secara spesifik kategorinya yaitu 3,6 persen masuk kategori kelas menengah atas, kemudian 1 persen kelas atas, 39,6 persen kelas bawah, dan 5,6 persen merupakan kelas yang sungguh-sungguh miskin. Mengingat jumlah penduduk Muslim di Indonesia mencapai 87,18 persen (BPS 2010), maka tak ayal lagi dominasi kelas menengah Muslim pun tak terhindarkan.

Berdasarkan data dari Middle Class Institute (MCI), lembaga think tank yang didirikan oleh majalah SWA, mereka melakukan studi secara kuantitatif dan kualitatif pada 2012-2013 di sembilan kota besar di Indonesia menghasilkan delapan wajah kelas menengah. Mereka yaitu expert, climber, aspirator, performer, trend-setter, follower, settler, dan flow-er (Yuswohady dan Gani 2015). Tumbuhnya kelas menengah Muslim baru ini lebih didukung karena tingginya konsumsi terhadap barang-barang elektronik dan kebutuhan sekunder lainnya yang telah menjadi gaya hidup baru bagi mereka. Bidang perbankan misalnya, selama kurun waktu lima tahun terakhir pertumbuhan bank umum syariah mencapai 11 bank umum, sementara

\footnotetext{
${ }^{5}$ Hal yang sama terjadi di beberapa daerah: Banyuwangi, Bima NTB, http://www.bbc.com/indonesia/indonesia40635043 diakses pada 25 Agustus 2017.
}

yang berbentuk unit usaha syariah telah mencapai 24 bank. Demikian pula yang terjadi pada fesyen, jilbab khususnya, saat ini telah menjadi penanda bagi Muslimah, bahkan sangat "revolusioner", sampai-sampai di sekolah negeri menengah umum baik SMP maupun SMA-- yang dulu di jaman Orde Baru menggunakan jilbab seolah tabu, namun saat ini 99 persen siswi Muslimah menggunakannya. Jika menjumpai siswi yang tidak memakai jilbab, hampir dipastikan ia beragama Kristen, Katolik, Hindu, Buddha, Konghucu atau lainnya. Bahkan sampai terjadi kasus di Sumatera Barat seorang siswi Kristen terpaksa menggunakan jilbab di sekolah negeri, yang mana hal ini dapat dikategorikan diskriminasi terhadap agama tertentu, ${ }^{5}$ sekurangkurangnya tiga peraturan dilanggar yaitu UndangUndang Perlindungan Anak, Undang-undang Hak Asasi Manusia, dan yang ketiga Undang-undang Sisdiknas. Institusi milik negara mesti menghargai keragaman siswa-siswinya, tidak boleh ada pemaksaan apapun bentuknya dari pihak mayoritas kepada minoritas, apalagi kepada peserta didik yang mana mereka masih sebagai anak-anak.

Bidang lain yang turut tumbuh secara ekonomi yakni kosmetik, dengan Wardah sebagai pemain utama yang berhasil menggaet pasar Muslimah Indonesia demikian besarnya. Dengan mengusung tagline Halal dari Awal dan Cantik dari Hati dalam iklannya maka Wardah telah mendapatkan tempatnya tersendiri sebagai garda terdepan dalam kosmetik bagi Muslimah Indonesia. Berikutnya yang ketiban berkah atas meningkatnya pendapatan ekonomi kelas menengah Muslim baru di Indonesia 
Jurnal Pemikiran Sosiologi Volume 4 No. 2, 2017

Kelas Menengah Muslim Baru dan Kontestasi Wacana Pluralisme di Media Sosial

Subkhi Ridho

adalah travel keluar negeri dengan tujuan ke tanah suci untuk melakukan umroh plus. Berdasarkan apologi wisata religi ke situs para nabi di Mekkah dan Madinah, plus melanglang ke negeri-negeri di sekitarnya seperti Turki, Dubai dan sejenisnya untuk membuat rileks kejiwaan mereka. Tidak mengherankan pula jika saat ini ada Muslim/Muslimah yang tiap tahun melakukan ibadah umroh demi membelanjakan pendapatannya di jalan ibadah, demikian argumen mereka. Sementara itu untuk melengkapi paket wisata, hotel pun berjamuran yang mengusung konsep hotel syar'i, demi kenyamanan dan keimanan batin yang tidak dapat ditawar lagi. Pasar hotel syar'i pun menjanjikan secara pendapatan ekonomi pemiliknya. Saat ini tumbuh halal tourism, yang mencoba menghadirkan paket halal dalam berwisata; makanan, penginapan, tempat-tempat yang dikunjungi, kesiapan venue dengan masjid/musholanya serta perlengkapan pendukung lainnya menjadikan kelas menengah Muslim baru ini betul-betul dimanjakan oleh berbagai varian pilihan gaya hidup di abad 21 yang berbalutkan identitas Islam.

Seiring tumbuhnya kelas menengah Muslim baru di Indonesia ini, beragam pula konsumsi Islam dalam sektor keuangan dan non-keuangan. Tidak ada kata sepakat secara tunggal apa yang dimaksud dengan kegiatan ekonomi Islam, tapi sekurang-kurangnya konsensus mengenai praktik ekonomi Islam bergerak di wilayah:

6 Hal ini sejalan dengan SK DIR. Bank Indonesia 32/34/kep/Dir 1999 pasal 1 (j), yang berbunyi: "Dewan Pengawas Syariah adalah dewan yang bersifat independen, yang dibentuk oleh Dewan Syariah Nasional
(1) meminjam dan meminjamkan uang tanpa bunga (riba);

(2) pembayaran zakat dan distribusinya kepada fakir miskin dan mereka yang membutuhkan;

(3) praktik-praktik investasi yang secara sosial dan moral bertanggung jawab dan tidak melanggar hukum Islam.

Untuk melegitimasi praktik bisnis berlabel syar'i tersebut dibimbing oleh para ulama yang ahli di bidang hukum Islam untuk memastikan kesesuaiannya dengan syariah Islam. ${ }^{6}$ Gambaran di atas sangat jelas menunjukkan kepada publik luas bahwa terjadi praktik meningkatnya konsumsi baru di kalangan kelas menengah muslim baru pasca reformasi di Indonesia. Pilihan hiburan bagi diri tidak hanya menjadi konsumsi bagi kaum sekuler semata, namun juga bagi mereka yang merasa dekat dengan Allah swt., dengan varian yang beragam mulai dari pariwisata, keuangan perbankan, perekonomian, fesyen, kewirausahaan, travel, hiburan, dan termasuk budaya populer. Pada aspek budaya bopuler, yang terbentuk karena dari kemajuan teknologi komunikasi dan informasi sehingga dapat disebarluaskan dengan masif. Diantara praktik budaya populer Islami tersebut yaitu film layar lebar, novel, musik Islami, apps bernuansa Islam adalah beberapa untuk menyebut bentuknya.

dan ditempatkan pada bank yang melakukan kegiatan usaha berdasarkan prinsip syariah, dengan tugas yang diatur oleh Dewan Syariah Nasional". 
Jurnal Pemikiran Sosiologi Volume 4 No. 2, 2017

Kelas Menengah Muslim Baru dan Kontestasi Wacana Pluralisme di Media Sosial

Subkhi Ridho

\section{Media Baru, Budaya Populer dan Wacana Pluralisme}

Media baru dengan segala kelebihan dan kekurangannya masing-masing telah menjadi arena yang diperebutkan oleh publik sebagai artikulasi gagasan maupun impian-impian tentang Indonesia hari ini dan di masa depan. Media baru yang ditopang oleh keberadaan internet oleh Sparks disebut sebagai media komunikasi yang dapat digunakan untuk memaksimalkan partisipasi warga dalam kehidupan politik dan sekaligus menjadi alat politik (Sparks 2001). Media baru melalui internet dapat dijadikan sebagai sarana partisipasi warga mampu menumbuhkan gairah berdemokrasi yang sebelumnya kurang menarik di kalangan anak muda berusia jelang dan pasca 20an tahun. Anak muda yang masih suka berkomunitas pada akhirnya mampu terwadahi dengan secara apik melalui internet. Studi dari Norris (2000: 121) menunjukkan bahwa internet dapat menjadi sarana untuk membangun komunitas virtual, selain itu internet juga dapat meningkatkan kapital sosial (social capital) dengan adanya saling tukar informasi antarpenggunanya (Rheingold 1995), dan yang berikutnya kaitannya dengan dalam menunjang demokratisasi, internet dapat memangkas jarak antara elit penguasa dengan konstituennya (Grossman 1995). Apa yang dikemukakan oleh para ilmuwan sosial tersebut saat ini telah menjadi fakta dan kenyataan yang sulit untuk dibantah. Para pengguna internet dengan media sosialnya mendapatkan kapital sosial dan bahkan kapital ekonomi mereka dengan maksimal. Adapun adanya akun-akun media sosial yang dimiliki elit politik dari eksekutif; bupati, gubernur, para menteri, bahkan presiden, maupun dari legislatif dapat menjadi ruang berbagi antara elit dengan warganya untuk memberikan masukan, saran, kritik kepada mereka tanpa rasa canggung lagi dan melalui prosedur yang tidak bertele-tele sebagaimana era sebelum internet. Inilah yang disebut bahwa internet melalui media sosial itu dapat telah meningkatkan partisipasi warga dalam mendukung demokratisasi di sebuah negara-bangsa. Inilah yang disebut oleh Norris bahwa media sosial telah mengurangi hambatan-hambatan keterlibatan warga dalam partisipasi berdemokrasi (the barriers to civic engagement). Hasilnya kehidupan publik menjadi lebih baik dan tercerahkan akibat dari keterbukaan dalam media sosial.

Internet mendasarkan cara kerjanya pada logika jaringan (networking logic) (Castells 2000). Dengan logika jaringan maka tidak ada lagi pusat, posisinya menjadi pinggir semua, yang menempatkan semuanya berada di ujung dan terbuka. Dengan jaringan yang semakin meningkat, maka simpulnya akan semakin ketemu. Inilah logika yang dimainkan oleh media sosial; mempertemukan seluruh aktor ketika seseorang terhubung dengan satu jaringan, maka koneksi lainnya akan didapatkan secara terbuka dan nyaris tanpa batas. Logika media sosial yang mampu mempertemukan seluruh pemilik akun di mana pun tanpa batasan geografis ini yang lantas digandrungi oleh kaum muda. Kegemaran untuk selalu aktif dan melakukan sesuatu demi eksistensi diri ini lantas menjadikan media sosial tidak dapat dilepaskan oleh anak-anak muda saat ini. William Strauss dan Neil Howe, keduanya merupakan sejarawan yang meminati kajian sejarah Amerika Serikat (AS) secara mendalam melalui bukunya yang berjudul Generations, menyebutkan adanya generasi Millenial (Y); mereka yang lahir 1982-2004, dan 
Jurnal Pemikiran Sosiologi Volume 4 No. 2, 2017

Kelas Menengah Muslim Baru dan Kontestasi Wacana Pluralisme di Media Sosial

Subkhi Ridho

generasi Z -bagi mereka yang lahir 2005-? serta nantinya generasi Alpha.

Apa konsekuensi dari pilihan Indonesia atas sistem demokrasi? Sekurang-kurangnya yaitu menjadikan media baru, internet, itu sebagai ruang publik bagi siapapun untuk menyebarluaskan gagasan, pandangan, pemikiran-pemikiran, maupun ideologi, yang bisa jadi dapat menjadi ancaman bagi demokrasi itu sendiri. Di dalam sistem demokrasi, dengan berbagai variannya, diajarkan tentang sikap menghargai kebinekaan, anti diskriminasi, kesetaraan, kebebasan berpendapat, berserikat, dan berkumpul. Atas nama demokrasi pula, internet sungguh telah menjadikan ruang publik menjadi sangat terbuka yang mengarah ke telanjang, jika mengambil istilah biologis tubuh manusia. Nyaris tidak ada lagi bagian tubuh yang dapat ditutupi oleh selembar kain, bahkan organ dalamnya sekalipun, dengan adanya teknologi x-ray dapat menyaksikan bagian terdalam tubuh manusia. Itulah logika internet. Gibson menyebutkan bahwa media baru itu menjadikan ruang maya sebagai "kerangkeng tak berhingga" (Gibson 1988). Di dalam ruang ini seseorang pada akhirnya tidak memiliki privasi karena semuanya serta terbuka. Hal inilah yang menjadikan ruang maya itu menghadirkan kenyataan maya (virtual reality), sebagai pengganti ruang fisik. Kenyataan maya menjadikan persebaran budaya populer pun mengalami peningkatan bagi para penikmatnya. Transaksi melalui e-commerce produk-produk budaya populer lantas semakin mudah diperoleh dan dinikmati oleh konsumen.

Budaya populer jika mengacu dari definisi yang dibuat oleh John Storey dan Dominic Strinati yaitu "dapat dipahami sebagai suara, gambar, dan pesan yang diproduksi secara massal dan komersial serta praktik pemaknaan terkait yang berupaya menjangkau sebanyak mungkin konsumen, terutama sebagai hiburan" (Heryanto 2015). Jadi budaya populer itu terbentuk karena adanya teknologi komukasi dan informasi dan didukung oleh media untuk menyebarluaskan. Bentuk-bentuk budaya populer yakni film, musik, busana, dan acara televisi. Dari praktik konsumsi terhadap komoditas tersebut maka lahir komunitas yang disebut sebagai "kelas menengah" yang hidup di kota dan dekat dengan dunia industri. Bagi Joel Kahn, kelas menengah itu "bukanlah anggota kelompok elit dalam pengertian filosofis, estetis, dan politis, dan bukan pula kaum proletariat atas kelas bawah yang baru" (Kahn 2001). Hal ini sejalan dengan definisi kelas menengah secara ekonomi, mereka juga kelompok yang tidak berada di atas namun juga tidak di bawah sama sekali, dan di dalamnya masih terbagi menjadi tiga kategori lagi. Kelas elit memiliki budayanya sendiri sesuai dengan taste yang mereka miliki, mereka pun dalam menyikapi keberadaan budaya populer dengan sikap yang merendahkan, karena menganggap sebagai budaya massal dan sekadar mengharapkan keuntungan finansial semata-mata, dan kurang mengindahkan estetika yang semestinya inheren di dalam sebuah budaya.

Jauh-jauh hari Marshall McLuhan menyampaikan bahwa media baru telah menyebabkan terjadinya desa global (global village), terjadi koneksi antara orang yang berada di pulau Seribu di DKI Jakarta dengan orang yang berada di kota Afrika Selatan pada jam yang sama meskipun secara geografis terpaut sangat jauh, berada ribuan mil, tentu selama terdapat jaringan internet. Hal inilah yang lantas menjadikan adanya persebaran nilai-nilai apapun, termasuk pluralisme. Melalui budaya populer media 
Jurnal Pemikiran Sosiologi Volume 4 No. 2, 2017

Kelas Menengah Muslim Baru dan Kontestasi Wacana Pluralisme di Media Sosial

Subkhi Ridho

baru, maka ruang untuk saling berbagi pun sangat terbuka. Di sini lah adanya pengenalan identitas diri mengenai siapa sesungguhnya diri dan kelompoknya. Pluralisme merupakan sebuah gagasan yang memuat nilai-nilai pengakuan dan pemahaman akan perbedaan; agama, etnis, ras, golongan. Di media sosial seseorang dapat menjadi dirinya sesuai fakta asalnya, atau menjadi diri yang lain yang berbeda dengan yang "asli".

Wacana pluralisme sendiri, khususnya pluralisme agama, pasca dikeluarkannya Keputusan Fatwa Majelis Ulama Indonesia, pada tanggal 29 Juli 2005 dengan Nomor 7/MUNAS VII/MUI/II/2005 tentang pluralisme, liberalisme, dan sekulerisme, lebih menjadi diskursus yang pembahasannya mundur kembali ke belakang. Mengingat definisi pluralisme agama oleh MUI dimaknai sebagai "menyamakan semua agama", sehingga kemudian dengan sendirinya pluralisme menjadi haram akibat tidak sesuai dengan ajaran Islam. Berikut definisi MUI mengenai pluralisme dalam fatwanya:

"Pluralisme agama adalah suatu paham yang mengajarkan bahwa semua agama adalah sama dan karenanya kebenaran setiap agama adalah relatif; oleh sebab itu, setiap pemeluk agama tidak boleh mengklaim bahwa hanya agamanya saja yang benar sedangkan agama yang lain salah. Pluralisme agama juga mengajarkan bahwa semua pemeluk agama akan masuk dan hidup berdampingan di surga."

Melihat dari definisi di atas, pembaca akan sangat mudah salah memahami makna pluralisme itu sendiri. Definisi ini menganggap bahwa semua agama saja. Tidak ada perbedaan signifikan antara satu dengan yang lainnya. Definisi tersebut bernuansa sinkretisme yang sangat kental, karena menyamaratakan, definisi sinkretisme yaitu "paham (aliran) baru yang merupakan perpaduan dari beberapa paham (aliran) yang berbeda untuk mencari keserasian, keseimbangan, dan sebagainya" (KBBI daring).

Sementara pluralisme menurut KBBI daring adalah "keadaan masyarakat yang majemuk (bersangkutan dengan sistem sosial dan politiknya)". Suatu kondisi sosial politik yang menyatakan bahwa pluralitas merupakan keniscayaan, termasuk di dalamnya pluralisme agama, diakuinya beragam agama yang ada di bumi ini. Pluralisme agama dapat dimaknai sebagai cara untuk menyikapi perbedaan agama yang ada di tengah-tengah kehidupan masyarakat. Sikap yang terbuka, tidak menghakimi keyakinan orang lain, tidak merasa paling benar sendiri, memiliki kemauan untuk mengapresiasi dan empati kepada setiap perbedaan yang ada. Dalam konteks Indonesia, mengacu pada UUD 1945 disebutkan dalam Pasal 29 ayat 2 yaitu: "Negara menjamin kemerdekaan tiap-tiap penduduk untuk memeluk agamanya masing-masing dan untuk beribadat menurut agamanya dan kepercayaannya itu". Dari sini sudah sangat jelas bahwa identitas yang melekat pada tiap warga negara Indonesia itu dijamin kehidupannya dan hak-haknya sekaligus, baik identitas agama, etnis, ras, jenis kelamin, maupun golongannya.

Di kalangan Islam sendiri terpolarisasi pasca dikeluarkannya fatwa MUI soal pluralisme, adanya faksi yang setuju dan tidak setuju dengan wacana pluralisme agama, meskipun ada juga kelompok yang memilih abstain dalam menyikapi wacana tersebut. Kelompok yang setuju atas wacana pluralisme agama sejak awal 2000an misalnya Ulil 
Jurnal Pemikiran Sosiologi Volume 4 No. 2, 2017

Kelas Menengah Muslim Baru dan Kontestasi Wacana Pluralisme di Media Sosial

Subkhi Ridho

Abshar Abdalla, Hamid Basyaib, Ahmad Sahal yang berasal dari Jaringan Islam Liberal (JIL), para intelektual dari kampus Paramadina Jakarta seperti Ihsan Ali Fauzi, Ahmad Gaus, UIN Jakarta: Komarudin Hidayat, Kautsar Azhari Noer, UIN Yogyakarta: M. Amin Abdullah, Abdul Munir Mulkhan, Hamim Ilyas, Wawan Gunawan, UIN Alaudin Makassar: Hamka Haq, termasuk dari kampus negeri seperti UGM: Samsu Rizal Panggabean, Muhadjir M. Darwin. Adapun di kalangan mudanya representasi intelektual muda NU yaitu Zuhairi Misrawi, Saidiman, Novriantini, Abd. Moqsith Ghazali, Guntur Romli, sementara dari intelektual muda Muhammadiyah ada Zuly Qodir, Ahmad Fuan Fanani, Zakiyudin Baidhawi, dari intelektual lain seperti Yudi Latif, Budhy MunawarRachman, untuk menyebut beberapa nama. Kelompok ini aktif melakukan sosialisasi, kampanye, melalui forum-forum seminar di berbagai kampus, melakukan kajian (workshop, pelatihan) secara intensif di kalangan anak-anak muda, menulis di media massa nasional, membuat jurnal, buletin atau media lain, serta melakukan program-program pelatihan bagi lembaga-lembaga pendidikan sekolah maupun pesantren dengan menyasar guru maupun siswa-siswinya.

Adapun faksi yang tidak sepakat dengan istilah pluralisme agama sejak diantaranya yaitu Hamid Fahmy Zarkasyi yang merupakan Pimpinan Ponpes Modern Gontor Ponorogo dan direktur INSISTS (Institute for the Study of Islamic Thought and Civilization), Adian Husaini alumnis ISTAC Malaysia, Adnin Armas merupakan Ketua Yayasan Keadilan untuk Semua (YKUS), dari kalangan muda yaitu Akmal Sjafril, adapun basisnya berasal dari Program Pascasarjana Pendidikan dan Pemikiran Islam
Universitas Ibn Khaldun Bogor, serta mereka yang tergabung di dalam Majelis Intelektual dan Ulama Muda Indonesia (MIUMI). Sejak tragedi 9/11 2001 pengeboman gedung World Trade Center di USA, kelompok yang kontra terhadap pluralisme agama ini meyakini adanya proyek liberalisasi pemikiran Islam di Indonesia melalui surat kabar, majalah, media elektronik; radio maupun televisi, dan penerbitan buku-buku. Adapun aktor-aktornya berasal dari kelompok-kelompok studi, LSM-LSM, universitas. Sementara isu-isu yang diusung dalam proyek liberalisasi pemikiran Islam menurut kelompok yang kontra pluralisme agama yaitu mengubah penafsiran al-Quran, pluralisme agama, feminisme dan kesetaraan gender yang dilakukan melalui Pusat Studi Wanita (PSW) di berbagai perguruan tinggi (Zarkasyi dalam Sjafril 2011: xixxxvi). Kondisi inilah yang mereka sebut sedang terjadi ghazwul fikriy; perang pemikiran terhadap umat Islam. Kelompok ini mengakui kurang aktif berwacana di dunia maya, sehingga suaranya kalah dengan kelompok Islam liberal yang jumlah minoritas (Sjafril 2011: viii). Menurut hemat saya apa yang diyakini oleh kelompok yang kontra terhadap pluralisme agama ini menunjukkan sikap inferioritas umat Islam di Indonesia, yang mewarisi sikap para Muslim pendahulu di era Orde Baru yaitu selalu merasa dimarjinalkan oleh negara. Sikapsikap seperti ini jika diwariskan secara terusmenerus kepada generasi selanjutnya justru akan membuat umat Islam vis a vis negara, yang dampaknya tidak kontraproduktif. Tentu saja masukan, saran maupun kritik kepada negara boleh saja dilakukan asalkan bertujuan konstruktif bukan sebaliknya, asal kritik yang tidak berdasar dan tidak menggunakan data ilmiah, apalagi asal beda dengan 
Jurnal Pemikiran Sosiologi Volume 4 No. 2, 2017

Kelas Menengah Muslim Baru dan Kontestasi Wacana Pluralisme di Media Sosial

Subkhi Ridho

negara. Indonesia sebagai negara yang lahir dari rahim kebinekaan; agama, etnis, ras, golongan, sejak awal kemerdekaan para pendiri bangsa yang berasal dari Islam, Kristen, Katolik, Hindu, Buddha telah membuat konsensus bersama mengenai keberagaman yang menjadi ruh bangsa. Bhinneka Tunggal Ika dalam kitab Sutasoma yang ditulis oleh Mpu Tantular dijadikan sebagai spirit dan pilar dalam berbangsa, "berbeda-beda tetapi satu jua".

\section{Pluralisme Agama di dalam Tafsir Islam dan Ujaran Mengenai Pluralisme}

Wacana pluralisme telah menjadi bahasan yang menarik perhatian tidak saja di Eropa, Amerika, namun juga di Indonesia. Mengingat Indonesia mayoritas penduduk beragama Islam, maka penting kiranya untuk melihat bagaimana akhlak al-Quran dalam menyikapi perbedaan. Di surat al-Baqarah: 62 , juga dengan redaksi yang agak berbeda di surat al-Maidah: 69 dan al-Hajj: 17. Dengan terjemahannya sebagai berikut:

"Sesungguhnya orang-orang mukmin, orang-orang Yahudi, orang-orang Nasrani, dan orang-orang Shabiin, siapa saja diantara mereka yang benarbenar beriman kepada Allah, hari kemudian, dan beramal saleh, mereka akan menerima pahala dari Tuhan mereka, tidak ada kekhawatiran terhadap mereka, dan tidak (pula) mereka bersedih hati".

Menurut Sayyid Husseyn Fadhlullah dalam tafsirnya menguraikan:

"Ayat ini menegaskan bahwa keselamatan pada hari akhirat akan dicapai oleh semua kelompok agama ini yang berbeda-beda dalam pemikiran dan pandangan agamanya berkenaan dengan akidah dan kehidupan dengan satu syarat: memenuhi kaidah iman kepada Allah, hari akhir, dan amal saleh" (Rakhmat 2006: 23).

Di dalam surat al-Nisa: 123-124, disebutkan bahwa keselamatan manusia itu ketika berpegang teguh pada keimanan Allah dan mengerjakan amal saleh, bukan karena yang lain-lain.

"(Pahala dari Allah) itu bukanlah menurut angananganmu yang kosong dan tidak (pula) menurut angan-angan Ahli Kitab. Barang siapa mengerjakan kejahatan, niscaya akan diberi pembalasan dengan kejahatan itu dan ia tidak mendapat pelindung dan tidak (pula) penolong baginya selain dari Allah. Barang siapa mengerjakan amal-amal saleh baik ia laki-laki maupun perempuan sedang ia orang yang beriman, maka mereka itu masuk ke dalam surga dan mereka tidak dianiaya walau sedikit pun

(Q.S. al-Nisa: 123-124).

Ulama terkemuka, Rasyid Ridha pada saat menjelaskan surat al-Baqarah ayat 62 , ia juga menghubungkan dengan surat al-Nisa: 123-124 dengan keterangan sebagai berikut:

"Hukum Allah itu adil dan sama. Ia memperlakukan semua pemeluk agama dengan sunah yang sama, tidak berpihak pada satu kelompok dan menzalimi kelompok yang lain. Ketetapan dari sunah ini ialah bahwa bagi mereka pahala tertentu dengan janji Allah melalui lisan Rasul mereka..."

(Ridha dalam Rakhmat 2006: 26).

Gagasan pluralisme di dalam al-Quran juga semakin kuat jika melihat firmannya:

"Andaikata Tuhanmu menghendaki, tentu Dia menjadikan manusia umat yang satu. Dan (tetapi) mereka senantiasa berbeda" (Q.S. Hud: 118); 
Jurnal Pemikiran Sosiologi Volume 4 No. 2, 2017

Kelas Menengah Muslim Baru dan Kontestasi Wacana Pluralisme di Media Sosial

Subkhi Ridho

Andaikata Allah menghendaki, niscaya kamu dijadikan-Nya satu umat saja" (Q.S. al-Maidah: 48).

Dari ayat-ayat tersebut kebinekaan merupakan keniscyaan yang tidak dapat diingkari dan ditolak, keberagaman adalah fitrah umat manusia, justru ketunggalan itu tidak dikehendaki oleh Allah swt. Lebih-lebih dalam ayat yang lain disebutkan: "Tidak ada paksaan dalam memasuki agama" (Q.S. alBaqarah: 256). Kehadiran Rasulullah Muhammad saw., itu pun sekadar sebagai penyampai wahyu kepada umat manusia bukan untuk memaksakan wahyu yang ia terima kepada orang-orang yang ada disekitarnya atau yang mengetahuinya. Sebagaimana termaktub dalam ayat berikut ini: "Kamu, bukan orang yang bisa menguasai mereka" (Q.S. al-Ghasiyah: 22); "Apakah kamu hendak memaksa manusia sehingga mereka beriman? (Q.S. Yunus: 99).

Mencermati beberapa ayat di dalam al-Quran mengenai sikapnya mengenai pluralisme agama telah sangat terang benderang bahwa keberagaman merupakan fitrah yang tidak dapat ditolak oleh umat manusia. Setiap individu akan dimintai pertanggungajwabannya dihadapan Tuhan sesuai dengan apa yang telah diperbuatnya di dunia. Tidak ada istilah individu satu memikul kesalahan, dosa yang dilakukan oleh individu lainnya. Setiap individu bebas melakukan apa pun yang diinginkan asalkan bertanggungjawab atas pilihan-pilihan yang telah ditentukan oleh dirinya. Hal ini sebagaimana tercantum dalam ayat berikut:

"Bagi tiap-tiap umat ada kiblatnya (sendiri) yang ia menghadap kepadanya. Maka berlomba-lombalah kalian (dalam membuat) kebaikan. Di mana saja kalian berada pasti Allah akan mengumpulkan (pada hari kiamat). Sesungguhnya Allah Maha Kuasa atas segala sesuatu"

(Q.S. al-Baqarah: 148).

Di sinilah teks al-Quran perlu dibaca sesuai dengan konteks, tidak dilepaskan sama sekali dari konteks yang pada akhirnya akan memproduksi pembacaan yang tekstualis, skripturalis, dan menjauhkan dari realitas yang dihadapi oleh masyarakat di mana ayat-ayat diperdengarkan. Tafsir transformatif dalam membaca al-Quran menjadi penting-meminjam istilah Moeslim Abdurrahman. Sebuah tafsir yang menempatkan al-Quran bukan sebuah benda mati yang diturunkan lima belas abad lalu dan dibaca apa adanya hari ini sehingga fungsi transformasi al-Quran tidak hidup dalam sanubari dan kehidupan umat Muslim, apalagi bagi umat lainnya. Tafsir transformatif membuka ruang bagi tumbuhnya gerakan sosial umat Islam untuk membebaskan belenggu ketidakadilan, diskriminasi, ketidaksetaraan, maupun kejahatan lain yang seringkali menimpa rakyat kecil yang terpinggirkan akibat dari struktur negara maupun sosial yang tidak berpihak kepada mereka (Abdurrahman 2009: 288-289).

Majalah Tempo edisi 28 Juli-3 Agustus pada tahun 2014 membuat investigasi secara khusus mengenai geliat kelas menengah Muslim baru yang diturunkan dalam rubrik 'liputan khusus'. Dalam laporannya Tempo menyebutkan bahwa pertumbuhan ekonomi berbasis syariah yang digerakkan oleh kelas menengah Muslim baru ini belum mampu menghadirkan wajah Islam yang toleran dan anti korupsi. Tantangan kelas menengah Muslim baru untuk dapat mencitrakan sebagai kelompok yang menjadi motor penggerak perubahan akan citra 
Jurnal Pemikiran Sosiologi Volume 4 No. 2, 2017

Kelas Menengah Muslim Baru dan Kontestasi Wacana Pluralisme di Media Sosial

Subkhi Ridho

Islam yang dianggap teroris, marah, galak terhadap kelompok minoritas maupun agama lain selayaknya direspon dengan bijak dan arif. Islam seyogyanya menjadi gerakan sosial yang mampu merespon berbagai kemungkaran yang diakibatkan perbedaan agama, etnis, ras, golongan mesti disambut secara positif dan direalisasikan dalam kehidupan berbangsa dan berbangsa. Kelas menengah Muslim baru tidak sekadar menjadi kelas konsumtif atas beragam produk keuangan dan non-keuangan yang menghipnotis konsumen karena merk yang berasal dari luar negeri.

Sebagaimana dijelaskan di atas, penggerak laju ekonomi beridentitaskan Islam adalah mereka yang masuk kategori kelas menengah Muslim baru yang muncul pasca reformasi. Hal itu juga tidak luput dari pertumbuhan ekonomi nasional yang di era pemerintahan SBY relatif stabil berada di kisaran 6 persen, sehingga dampaknya dapat dirasakan oleh kelas menengah Muslim baru. Meskipun sejak 2011 pada saat masih berada di angka 6,2 persen, trennya menurun pada 2012 menjadi 5,9 persen; 2013: 5,8 persen; pada 2014 menjadi 5,0 persen pada saat pergantian pemerintahan kepada Presiden Joko Widodo.

Media sosial hari ini telah menjelma menjadi salah satu sarana paling efektif dan efisien untuk melakukan propaganda kepada pihak lain yang tidak disukai untuk menjatuhkan karakter seseorang, apalagi yang sedang berkompetisi dalam pesta demokrasi. Dengan logika jaringan yang dimiliki oleh media sosial, maka dengan mudahnya sebuah informasi tersebar secara cepat, meskipun kebenaran seringkali jauh panggang dari api. Munculnya figur Jokowi sebagai presiden RI ketujuh, tidak lepas dari dukungan PDIP, Nasdem, PKB,
Hanura, PKPI, dan gelombang relawan di berbagai daerah serta media sosial yang menunjukkan figur sederhana dan pekerja dari sosok Jokowi. Sementara kandidat penantangnya Prabowo Subianto, didukung oleh Gerindra, PKS, PAN, PPP, Golkar, adapun Demokrat secara dukungan resmi tidak masuk di kedua kubu. Hal ini dapat dilihat dari awal Prabowo-Hatta yang mencoba memainkan isu agama untuk menjatuhkan pasangan Jokowi-JK. Munculnya tabloid 'Obor Rakyat' misalnya yang menyatakan bahwa Jokowi adalah komunis dan tidak islami banyak mengambil ceruk suara di kantong-kantong pemilih Muslim. Pada akhirnya isu identitas agama di Pilpres 2014 tidak terlalu signifikan menggerus pemilih Jokowi di bilik suara, karena pasangan Jokowi-Hatta tetap terpilih sebagai presiden dan wakil presiden RI. Namun demikian, nampaknya kekalahan di pilihan presiden 2014 tersebut berdampak terus hingga hari ini.

Berbeda dengan pilpres 2014, Pilkada yang sudah dimulai dilakukan secara serentak sejak 2015 lalu, justru permasalahan identitas agama dapat dijadikan komoditas politik dalam Pilkada DKI 2016 lalu yang menghadirkan pasangan Agus-Silvi, Basuki-Djarot, dan Anies-Sandi di putaran pertama. Sementara masuk pada putara kedua, menyisakan Basuki-Djarot versus Anies Sandi. Kandidat pertama didukung PDIP, Nasdem, PKB, Golkar, PPP, Hanura, sementara kandidat kedua didukung oleh Gerindra, PKS, dan belakangan oleh Demokrat meskipun tidak secara resmi. Sebagaimana diketahui bersama Basuki Tjahaya Purnama yang lebih populer disebut Ahok merupakan seorang Kristen dan beretnis Cina. Sentimen Kristen dan Cina dapat digunakan oleh kandidat lawan untuk "menjatuhkan" Ahok di putaran kedua, dengan suara 41,8 persen untuk 
Jurnal Pemikiran Sosiologi Volume 4 No. 2, 2017

Kelas Menengah Muslim Baru dan Kontestasi Wacana Pluralisme di Media Sosial

Subkhi Ridho

Ahok dan 58, 2 persen untu Anies. Didahului dengan drama ungggahan video oleh Buni Yani di laman akun facebook yang dimilikinya, dengan menghilangkan transkrip kata "pake" surat alMaidah, sehingga yang diterima oleh publik adalah kalimat "Jangan mau dibohongi surat Al-Maidah 51". Hal itu lantas membangkitkan amarah dan sentimen sebagian umat Islam yang berhasil dipersuasi oleh kelompok anti Ahok. Unggahan video Buni Yani yang memotong dari durasi sekitar 90 hanya menjadi 3 menitan ini menjadi viral yang ujungujungnya melahirkan drama demonstrasi massa besar-besaran di silang Monas Jakarta, Sudirman, Thamrin dan sekitarnya hingga berepisode layaknya sebuah sekuel sinetron di televisi. Aksi kelompok anti Ahok yang paling menyita perhatian adalah pada saat mereka menamai Aksi Bela Islam 411 dan 212, pilihan angka tersebut karena demonstrasi dilakukan pada hari Jumat, tanggal 4 November dan 2 Desember 2016 dengan tuntutan tangkap dan adili Ahok. Dengan dalih penodaan agama yang dilakukan oleh Gubernur DKI Basuki Tjahaya Purnama, demonstrasi massa besar-besaran tersebut berhasil menjebloskan gubernur DKI yang sedang menjabat ke jeruji besi setelah melalui rangkaian sidang peradilan yang berhasil menyita perhatian publik luas, tidak sekadar publik Jakarta. Ini akibat dari penggunaan media sosial yang diarahkan pada politisasi dengan menggunakan sentimen agama sebagai senjata agama. Sekiranya pluralisme agama sudah menjadi ruh di setiap warga bangsa maka peristiwa yang menimpa Ahok tidak akan terjadi lagi di masa depan.

Selain peristiwa di atas, kita dapat dengan mudah menjumpai ajaran-ajaran ekstrimisme dan radikalisme di media sosial, meskipun mereka tidak mendapat tempat di media arus utama. Ajakan maupun seruan untuk mendirikan khilafah Islamiyah (negara Islam) yang dilakukan oleh Hizbut Tahrir Indonesia(HTI) melalui tokohnya Ismail Yusanto, Felix Siauw, Majelis Mujahidin Indonesia (MMI) yang dimotori oleh Irfan S. Awwas, maupun Jamaah Anshorut Tauhid (JAT) di bawah komando Abu Bakar Ba'asyir dengan mudah mereproduksi pesan anti kebinekaan. Reproduksi ujaran kebencian maupun ajakan anti Pancasila, anti pluralisme agama, dapat dijumpai di media sosial yang informasinya bersumber dari laman-laman seperti www.eramuslim.com, panjimas.com, Islampos.com, https://www.hidayatullah.com/, https://www.nahimunkar.com/, portalpiyungan.cf, arrahmah.com, penaaksi.com, dan voa-islam.com untuk menyebut beberapa.

Selain itu media sosial di Twitter yang dimiliki oleh akun@malakmalakmal misalnya, dengan leluasanya mengampanyekan Indonesia tanpa Jaringan Islam Liberal (ITJ) di berbagai daerah; Jakarta, Bogor, Bekasi, Tangerang, Tangerang Selatan, Depok, Malang, Yogyakarta, Padang, Gorontalo. Sebagaimana dalam buku yang ditulisnya dengan judul "Islam Liberal 101" Sjafril (2011: 67 79) mengatakan bahwa telah terjadi perang pemikiran (ghazwul fikriy) terhadap umat Islam, salah satunya yang gencar yaitu isu "pluralisme agama untuk memandulkan keberadaan agamaagama itu sendiri". Akmal Sjafril merupakan alumnus jurusan teknik sipil ITB dan Program Pascasarjana Universitas Ibn Khaldun Bogor dengan beasiswa dari Baznas dan Dewan Dakwah Islamiyah Indonesia (DDII), ia merupakan Kepada Divisi Penelitian dan Pengembangan Gerakan Indonesia Tanpa JIL pusat. Gerakan ITJ juga didukung oleh 
Jurnal Pemikiran Sosiologi Volume 4 No. 2, 2017

Kelas Menengah Muslim Baru dan Kontestasi Wacana Pluralisme di Media Sosial

Subkhi Ridho

artis Fawzi Baadila. Forum lain yang disebarluaskan sebagai forum anti pluralisme agama adalah Islamic Fair di Yogyakarta, yang selalu menghadirkan Salim A. Fillah sebagai ustadz ala gerakan anti pluralisme. Instagram sebagai media sosial yang sedang tren di kalangan anak muda Indonesia, karena fiturnya beragam dan dapat digunakan sebagai sarana ekspresi diri serta eksistensi yang menarik dibanding media sosial lain. Instagram menjadi sarana bagi kelompok anti pluralisme agama, melalui akun@itjjogja @terasdakwah misalnya mengampanyekan tentang kepedulian terhadap alAqsha, ajakan berdonasi, berzakat. Jika dicermati secara lebih mendalam dibalik itu semua mereka sedang melakukan bisnis buku, penerbitan, pernakpernak aksesoris beridentitas Islam, berjualan kopi, siomay, dll., sebagaimana dilihat dari akun @ariadecan, @yogiprastiyo @berrielmaky untuk menyebut beberapa nama. Kelompok kelas menengah Muslim baru ini menggunakan idiomidiom Islam untuk kelancaran bisnis mereka masing-masing. Pada saat mereka menolak liberalisme dengan pluralisme agama dan sekulerisme di dalamnya, disitulah mereka sedang melakukan komodifikasi Islam dalam kehidupan sehari-hari. Sementara sekulerisme misalnya ingin memosisikan agama pada wilayah yang sakral sehingga tidak mudah dimanipulasi oleh kepentingan duniawi semata, seperti jualan komoditas barang seperti fesyen, kosmetik, ataupun lainnnya.

\section{E. Kesimpulan}

Hari ini dengan menjamurnya media sosial kita sedang mengalami era post-truth, "istilah yang berhubungan dengan atau mewakili situasi-situasi dimana keyakinan dan perasaan pribadi lebih berpengaruh dalam pembentukan opini publik dibandingkan fakta-fakta yang obyektif' kamus Oxford (2016). Hoax menjadi mantera ampuh untuk menghilangkan daya kritis seseorang ketika menerima informasi yang diterima, begitu saja disebarluaskan kepada orang lain, karena dianggapnya sebagai sebuah kebenaran. Proses check and balances menjadi sangat tipis, bahkan hilang. Potong kompas informasi yang berseliweran di tengah-tengah kehidupan berbasis internet menjadi sebuah kelaziman dan kelumrahan, sehingga terkesan muncul nada permakluman ketika beredar informasi yang menyesatkan bagi para konsumen informasi. Padahal di dalam Islam, ajaran tabayyun semestinya didahulukan ketika terdapat berita maupun peristiwa yang terjadi. Saat ini kita disuguhi oleh industrialisasi hoax dan justru menjadi penghidupan oleh sebagian kecil dari orang-orang disekitar kita.

Internet dengan rumus-rumus algoritmanya justru membuat pilihan-pilihan dan pesan kepada pengguna internet semakin mengerucut pada satu tema saja atau biasa disebut filter bubble theory (Pariser, 2011). Internet dengan media sosialnya justru menjadi alat untuk menyebarluaskan uajranujaran kebencian yang membuat situasi masyarakat dunia maya semakin tertuju pandangan-pandangan individu yang semakin subyektif dari waktu ke waktu. Pandangan pribadi menjadi sentral atas penilaian sebuah isu, bukan sebaliknya yaitu pandangan yang obyektif, benar, bahkan yang telah 
Jurnal Pemikiran Sosiologi Volume 4 No. 2, 2017

Kelas Menengah Muslim Baru dan Kontestasi Wacana Pluralisme di Media Sosial

Subkhi Ridho

teruji secara ilmiah berdasarkan data dan fakta. Pengguna media sosial memosisikan dirinya sebagai agen sentral dari situasi terkini. Ia menjadi pembenar atas sebuah peristiwa maupun berita yang didapatkan meskipun sekadar menerima tanpa didahului proses klarifikasi dan tes kebenaran terlebih dahulu.

Kelas menengah Muslim baru yang semestinya menjadi agen perubahan sosial justru belum dapat diandalkan sesuai harapan. Kelas menengah Muslim baru masih memosisikan Islam di era Presiden Jokowi ini sebagai kelompok yang dimarjinalkan sebagaimana di era Orde Baru. Penempatan umat Islam yang inferior ini menjadikan kelas menengah Muslim baru ini masih sibuk pada urusan domestik bangsa, seperti melahirkan gerakan Indonesia tanpa JIL yang mengusung pemikiran-pemikiran sekulerisme, pluralisme, liberalisme, maupun kesetaraaan gender di ruang publik. Memusuhi sesama anak bangsa terkesan lebih didahulukan, dengan dalih saat ini sedang terjadi ghazwul fikriy terhadap umat Islam, sehingga generasi mudanya harus terlibat dalam perang pemikiran tersebut. Pada saat bangsa lain sedang memikirkan aksi kolaboratif antar berbagai elemen untuk membangun negerinya masing-masing, bahkan sedang membuat global cizitenship akibat penetrasi internet yang luar biasa, sehingga tidak sekadar menjadi warga di sebuah negara tertentu melainkan menjadi warga global yang konsekuensinya mengurusi permasalahan-permasalahan global; global warming, pembalakan liar terhadap hutan, perdagangan manusia, krisis lingkungan, ketersediaan pangan. Justru kelas menengah Muslim baru di Indonesia ini tampaknya masih saja berpikiran secara vis a vis antara umat Muslim versus negara.

\section{Daftar Pustaka}

Abdurrahman, Moeslim. 2009. Suara Tuhan, Suara Pemerdekaan. Yogyakarta: Kanisius.

Castells, Manuel. 1996. The Rise of the Network Society, The Information Age: Economy, Society and Culture Vol. I. Cambridge, MA; Oxford, UK: Blackwell.

Fealy, Greg dan Sally White. 2008. Expressing Islam: Religious Life and Politics in Indonesia. Singapore: ISEAS.

Geertz, Clifford. 1992b. Tafsir Kebudayaan. Yogyakarta: Kanisius.

Ghazali, Abd. Moqsith. 2009. Argumen Pluralisme Agama, Membangun Toleransi Berbasis AlQur'ran. Jakarta: KataKita.

Haris, Syamsuddin. 2014. Masalah-Masalah Demokrasi dan Kebangsaan Era Reformasi. Jakarta: Buku Obor.

Haryatmoko. 2010. Dominasi Penuh Muslihat, Akar Kekerasan dan Diskriminasi. Jakarta: Gramedia Pustaka Utama.

Heryanto, Ariel. 2015. Identitas dan Kenikmatan: Politik Budaya Layar Indonesia. Jakarta: KPG.

Ibrahim, Idi Subandy. 2011. Kritik Budaya Komunikasi. Yogyakarta: Jalasutra.

Kahn, Richard dan Douglas Kellner. 2004. "New Media and Internet Activism: From the 'Battle of Seatle' to Blogging. Journal of New Media and Society Vol 6 (1).

Kharas, Homi. 2010. The Emerging Middle Class In Developing Countries. Working Paper. OECD Development Centre.

Kuntowijoyo. 2001. Muslim Tanpa Masjid. Bandung: Mizan.

Maarif, Ahmad Syafii. 2010. "Politik Identitas dan Masa Depan Pluralisme Indonesia" dalam Ihsan Ali Fauzi dan Samsu Rizal Panggabean (eds.), Politik Identitas dan Masa Depan Pluralisme Kita. Jakarta: Paramadina.

Norris, Pippa. 2000. A Virtuous Circle: Political Communications in Postindustrial Societies. Cambridge: Cambridge University Press.

Pambudy, Ninuk Mardiana. 2012. “Gaya Hidup Suka Mengonsumsi dan Meniru: Beranikah Berinovasi" dalam Majalah Prisma edisi Vol. 31, No. 1. 2012. 
Qodir, Zuly. 2010. Islam Liberal: Varian-Varian Liberalisme Islam di Indonesia 1991-2002. Yogyakarta: Yayasan LKiS.

Rachman-Budhy Munawar. 2010. Reorientasi Pembaruan Islam: Sekulerisme, Liberalisme, dan Pluralisme Paradigma Baru Islam Indonesia. Jakarta: LSAF dan Paramadina.

Rakhmat, Jalaluddin. 2006. Islam dan Pluralisme, Akhlak Quran Menyikapi Perbedaan. Bandung: Mizan.

Rheingold, Howard. 1995. The Virtual Community: Homesteading on the Electronic Frontier. Reading, MA: Addison-Wesley Pub.Co.

Sjafril, Akmal. 2011. Islam Liberal 101. Tangerang Selatan: Indie Publishing.

Sparks, C. 2001. "The Internet and the Global Public Sphere" dalam W.L. Bennett dan R.M. Entman (eds.), Mediated Politics: Communication in the Future of Democracy. Cambridge: Cambridge University Press.

Strinati, Dominic. 1995. An Introduction to Theories of Popular Culture. London: Routledge.

Supelli, Karlina. 2010. "Ruang Publik Dunia Maya" dalam F. Budi Hardiman (ed.), Ruang Publik Melacak Partisipasi Demokrasi dari Polis sampai Cyberspace. Yogyakarta: Kanisius.

Tanthowi, Pramono U. 2005. Kebangkitan Politik Kaum Santri, Islam dan Demokratisasi di Indonesia, 1990-2000. Jakarta: PSAP.

Yuswohady dan Kemal E. Gani. 2015. 8 Wajah Kelas Menengah. Jakarta: PT Gramedia Pustaka Utama.

2015. Marketing to the Middle Class Muslim. Jakarta: PT Gramedia Pustaka Utama.

\section{Sumber Majalah:}

Prisma. 2012. Edisi Vol. 31, No. 1. 2012.

Tempo. 2012. Edisi 20-26 Februari 2012.

Tempo. 2012. Edisi 28 Juli-3 Agustus 2014. 